\title{
Академик М. С. Вовси и «дело врачей»»
}

К концу 30-х годов XX века в СССР несомненными лидерами столичных терапевтов были М. П. Кончаловский, Е. Е. Фромгольд и Р. А. Лурия ${ }^{1}$ - об этом свидетельствуют их публикации, официальные должности, материалы всесоюзных съездов терапевтов и Московского научного общества терапевтов, воспоминания современников. Вместе с Г. Ф. Лангом (Ленинград) и Н. Д. Стражеско (Киев) они возглавляли советскую клинику внутренних болезней. Из более молодого поколения клиницистов стремительно выдвигались трое А. Л. Мясников в Ленинграде, а в Москве - Э. М. Гельштейн, партийный выдвиженец, блестящий врач и ученый, возглавивший кафедру факультетской терапии 2-го ММИ и сменивший Е. Е. Фромгольда (после 1937 г.) в качестве товарища председателя Московского терапевтического общества, и М. С. Вовси.

Мирон Семёнович Вовси родился 1 (12) мая 1897 г. в поселке Краславка (Креславль) Двинского уезда (Витебская губерния, ныне - Латвия), ${ }^{2,3}$ в семье торговца лесом. ${ }^{4}$ Окончив Рижское реальное училище, он в 1914 г. поступил в Юрьевский университет (г. Тарту, Эстония). По воспоминаниям дочери, Любови Мироновны

1250 лет ММА им. И. М. Сеченова. Биографический словарь. - Москва, 2008. - С. 113.

2 Российская еврейская энциклопедия. - Т. 1. - Москва, 1994. - С. 235.

3 Жизнеописание. - Архив АМН СССР - РАМН, ф. 2 (ВИЭМ), оп. 2, ед. хр. 81, л. 310.

${ }^{4}$ Там же. 
Вовси, отец мечтал стать математиком или физиком, однако приём евреев на эти факультеты был ограничен, и он поступил на медицинский - по его собственному выражению, «врачом стал невольно, по недоразумению». Во время Первой мировой войны в связи с оккупацией Юрьева университет перевели в Воронеж, а М. С. Вовси в 1918 г. перебрался в Москву, перевелся на медицинский факультет Московского университета и окончил его в 1919 г. (первый советский выпуск врачей). Добровольцем он ушел на гражданскую войну; служил старшим врачом 51-го полка 6-й Петроградской пролетарской дивизии.

В 1921 г. он был откомандирован на курсы врачей Наркомздрава РСФСР, со 2 февраля 1922 г. состоял ординатором факультетской терапевтической клиники 1-го Московского государственного университета (МГУ) (избран на три года), ${ }^{5}$ где работал под руководством профессора Д. Д. Плетнева и его ассистентов М. И. Вихерта и В. Н. Виноградова. В своих воспоминаниях сотрудник кафедры Вовси профессор И. С. Шницер писал, что именно Д. Д. Плетнева М. С. Вовси считал своим учителем. ${ }^{6}$ Мы располагаем главным аргументом в пользу такого утверждения: сам Мирон Семенович в своем докладе к 25-летнему юбилею кафедры терапии № 1 ЦИУ врачей назвал себя учеником Дмитрия Дмитриевича Плетнева.

С 1925 г. М. С. Вовси - «научный сотрудник 1-го разряда» (то есть старший научный сотрудник) клинического отдела Клинического института функциональной диагностики и экспериментальной терапии при 1-ом МГУ (в дальнейшем - Медико-биологический институт Главнауки), где работал под руководством В. Ф. Зеленина. ${ }^{8}$ В автобиографии М. С. Вовси можно прочитать, что «в течение шести лет работал также в Издательстве Центр Комитета Медсантруд, где основал журнал «Советский врач»:9 это издание появилось в 1930 г.

5 ЦАГМ, ф. 1609, оп. 1, д. 578, л. 74.

6 Шницер И. С. Встречи, воспоминания. - Кн. 2-я. - Рукопись в семейном архиве. - С. 87-98.

7 Доклад М. С. Вовси к 25-летнему юбилею первой кафедры терапии. Личный архив Т. Н. Герчиковой.

8 ЦАГМ, ф. 1609, оп. 1, д. 992, л. 1-10.

9 Жизнеописание. - Архив АМН СССР - РАМН, ф. 2 (ВИЭМ), оп. 2, ед. хр. 81, л. 310. 
на базе выходившего в 1924-1929 гг. «Вестника современной медицины»; под новым названием журнал стал освещать главным образом вопросы участия врачей в общеполитической и профессиональной жизни, проблемы социальной, клинической и экспериментальной медицины. ${ }^{10}$

О направлении основных научных интересов М. С. Вовси в 1920-е гг. наглядно свидетельствуют два следующих документа. В характеристике, подписанной в 1925 г. директором факультетской терапевтической клиники М. И. Вихертом (в 1924 г. он стал преемником Д. Д. Плетнева, который перешел на кафедру госпитальной терапии) - одним из пионеров нефрологических исследований в СССР, указано, что за время пребывания в клинике научные работы Вовси носили как «научно литературный характер» (обзорные работы о гипертонии и о хрониосепсисе), так и «клинический или экспериментально-клинический характер» (о клинике сулемовых отравлений и о роли печени в обмене аминокислот). ${ }^{11}$ Следовательно, почечная тематика в 1920-е гг. еще не была для М. С. Вовси предметом специальной разработки, в отличие от М. И. Вихерта («Изменения функции больных почек», 1922; «От Брайта до наших дней», 1929) и Е. М. Тареева («Анемия брайтиков», 1929). Характерно, что в руководстве Вовси по болезням системы мочеотделения (1960) работы М. И. Вихерта не упоминаются. Таким образом, у нас нет оснований говорить, что в факультетской клинике 1 МГУ сложилась нефрологическая школа Вихерта, к которой можно было бы отнести не только Е. М. Тареева, но и М. С. Вовси.

Второй документ, характеризующий направленность научных интересов молодого врача исследователя, - отчет о его полугодовой научной командировке в Германию (1927). ${ }^{12}$ Работая в Берлине, Киле, Франкфурте-на-Майне в клиниках и лабораториях Г. фон Бергмана

10 Левит М. М. Медицинская периодическая печать России и СССР (1792-1962). - Москва, 1963. - С. 192-193.

11 Отзыв (о докторе Вовси М. С.). - Архив АМН СССР - РАМН, ф. 2 (ВИЭМ), оп. 2, ед. хр. 81, л. 328.

12 Отчет о научной командировке Вовси М. С., научного сотрудника 1-го разряда Медико-биологиченского института. - Архив АМН СССР РАМН, ф. 2 (ВИЭМ), оп. 2, ед. хр. 81, л. 320. 
и других видных представителей немецкой медицины, он знакомился с методами изучения водного и минерального обмена, химического состава тканей, определения массы крови, микрофото-капилляроскопии, рентгенодиагностики патологии кишечника и т. д. Даже в клинике профессора Ф. Фольгарда, европейского авторитета в вопросах почечной патологии, его интересовали только методы выявления нарушений кислотно-основного равновесия. Нет сомнений, болезни почек стали занимать все более видное место в научных интересах М. С. Вовси только с 1930-х гг. и без видимой связи с М. И. Вихертом.

В 1930 г., когда В. Ф. Зеленин, оставив за собой клинический отдел, перешел на кафедру госпитальной терапии 2-го Московского медицинского института, он предложил реорганизацию аппарата дирекции Медико-биологического института, которая предусматривала, в частности: «Просить Главнауку вместо должности второго заместителя учредить должность старшего врача, на каковую должность просить назначить сотрудника 1-го разряда М. С. Вовси с окладом ставки зам. директора». ${ }^{13}$ Этот документ свидетельствует, что к началу 30-х годов М. С. Вовси был одним из ведущих сотрудников Медико-биологического института и имел особый «научный вес» в глазах основателя и первого директора института В. Ф. Зеленина. Однако после его ухода М. С. Вовси оставался здесь недолго, что зафиксировано в приказе по институту: «Отчислить ст. научного сотрудника по отд. внутр. бол. М. С. Вовси от занимаемой должности с 26/II с. г., согласно заявлению. Основание: заявление М. С. Вовси и согласие дирекции. Директор Ин-та С. Левит» (1933). А дружеские отношения Зеленина и Вовси остались на всю жизнь. ${ }^{14}$

С 1931 г. М. С. Вовси заведовал 2-м терапевтическим отделением Басманной больницы, с 1934 г. - терапевтическим отделением Боткинской (Солдатенковской) больницы. В 1935 г. на базе 11-го корпуса этой больницы была создана третья (наряду с кафедрами

13 Выписка из протокола заседания Правления Медико-биологического института от 5 окт. 1930 г. - Архив АМН СССР - РАМН, ф. 2 (ВИЭМ), оп. 2, ед. хр. 81, л. 338.

14 Бородулин В. И., Зеленин А. В. Владимир Филиппович Зеленин: время и жизнь. - Москва, 2012. - С. 140-141. 
Р. А. Лурии и Д. Д. Плетнева) кафедра терапии Центрального института усовершенствования (ЦИУ) врачей, и доцент М. С. Вовси был утвержден руководителем кафедры. После защиты докторской диссертации и утверждения в звании профессора (1936) он был вновь избран по конкурсу заведующим этой кафедрой, которой руководил до конца своей жизни.

Сначала у него было всего четверо сотрудников - всю педагогическую и лечебную работу выполняли ординаторы 11-го корпуса Боткинской больницы. В 1937 г. к нему пришли преподаватели с ликвидированной (после ареста ее руководителя Д. Д. Плетнева) кафедры № 2 ЦИУ врачей - доценты А. З. Чернов и Г. Ф. Благман, ассистенты А. Л. Шляхман, С. Г. Вайсбейн, В. Е. Фрадкина и др.; сама кафедра стала называться второй кафедрой терапии ЦИУ. Совершенствовались методы преподавания: семинарские занятия чередовались с учебными обходами, лекции - с разборами больных в аудитории, были введены занятия по электрокардиографии, рентгенодиагностике, лабораторному делу.

В 1941 г. М. С. Вовси чудом избежал гибели. Накануне начала войны, по воспоминаниям Л. М. Вовси, «папа собирался поехать со мной в Латвию, навестить 80-летнего отца, моего дедушку, но по случайному стечению обстоятельств наш отъезд отложился на неделю. И это нас спасло - как стало известно после окончания фашистской оккупации, дедушка был убит сразу, а папин брат с семьей провели более двух лет в гетто и были уничтожены перед приходом Красной Армии».

В августе 1941 г. беспартийный 44-летний профессор М. С. Вовси был назначен главным терапевтом Красной армии. ${ }^{15}, 16$ O том, как произошло это назначение, мы знаем «из первых рук»начальник Главного военно-санитарного управления (ГВСУ) генерал-полковник медицинской службы Е. И. Смирнов писал:

15 Алексанян И. В., Шульцев Г. П., Кнопов М. Ш. Выдающийся ученый, терапевт и педагог (к 90-летию со дня рождения М. С. Вовси) // Клиническая медицина, 1987; 9: 128-129.

16 Кнопов М. Ш. и соавт. Мирон Семенович Вовси - выдающийся ученый, терапевт и педагог (к 110-летию со дня рождения) // Терапевтический архив, 2007; 4: 93-95. 
«Решая вопрос о подборе кандидата на должность главного терапевта Красной Армии, я счел нужным посоветоваться с ленинградским профессором, широко известным клиницистом Г. Ф. Лангом. Позвонил ему по телефону. Он попросил у меня сутки на обдумывание и ровно в это же время на другой день позвонил мне и сказал, что может рекомендовать только одного кандидата - профессора Мирона Семеновича Вовси... Я безоговорочно поддержал эту кандидатуру, и ее выбор рассматриваю как исключительную удачу. Проф. М. С. Вовси полностью оправдал доверие. Он был блестящим главным терапевтом Красной Армии». ${ }^{17}$

Генерал-майор медицинской службы (1943) М. С. Вовси стал одним из создателей отечественной военно-полевой терапии. По его собственным словам: «В Отечественную войну мы пришли еще без сложившихся организационных форм военно-полевой терапии и принципов построения лечения терапевтических больных на войне». В годы Великой Отечественной войны М. С. Вовси участвовал в разработке и внедрении системы терапевтических мероприятий в войсках, изучал особенности заболеваний у военнослужащих в действующей армии; под его руководством и при его непосредственном участии создавались указания ГВСУ Красной Армии по лечению в условиях военного времени крупозной пневмонии, острого нефрита, ревматизма и др. заболеваний; проводились фронтовые и армейские научные конференции военных врачей-терапевтов; им была подробно описана клиника огнестрельных ранений легких. ${ }^{18}$ Созданная в годы войны система организации терапевтической помощи, обеспечивающая ее квалифицированное оказание в войсковом, армейском и фронтовом, а также в тыловых районах, полностью себя оправдала: 90,6\% больных возвратилось в строй, увольнение не превышало 7\%, небольшой была летальность. ${ }^{19}$ На должности главного терапевта Красной (затем - Советской) Армии М. С. Вовси оставался до 1950 г.

17 ЦАМО РФ, личное дело М. С. Вовси, N 0467015.

18 Шульцев Г. П. 75-летие со дня рождения М. С. Вовси // Терапевтический архив, 1972; XLIV, 8: 115-117.

19 Внутренние болезни: Военно-полевая терапия / Под ред. А. Л. Ракова, А. Е. Сосюкина. - Санкт-Петербург, 2003. - С. 12. 
В конце 1944 г. на той же базе в Боткинской больнице была создана дочерняя кафедра клинической и военно-полевой терапии при военном факультете ЦИУ врачей, просуществовавшая семь лет; обеими кафедрами руководил М. С. Вовси. На кафедре терапии работали профессор И. С. Шницер, доценты Г. Ф. Благман, Н. П. Рабинович, ассистенты М. И. Шевлягина, В. Е. Фрадкина, С. Г. Вайсбейн, А. Л. Шляхман, Н. С. Берлянд и др. Заместителем начальника кафедры военно-полевой терапии был Б. Е. Вотчал, старшим преподавателем - А. 3. Чернов, преподавателями работали Е. В. Пославский, М. И. Дорохова и Г. П. Шульцев, были и вольнонаемные преподаватели. ${ }^{20}$ Сотрудники кафедр (Г. Ф. Благман, Б. Е. Вотчал, М. Я. Ратнер, А. З. Чернов, М. И. Шевлягина, И. С. Шницер, Г. П. Шульцев) выполнили и защитили докторские диссертации. До 1950 г. кафедры проводили занятия по завершению образования врачей, выпущенных во время войны без диплома (так называемых зауряд-врачей), до 1952 г. циклы специализации, в дальнейшем - только циклы усовершенствования врачей по терапии.

В 1948 г. М. С. Вовси был избран академиком Академии Медицинских наук (АМН) СССР «как выдающийся клиницист-терапевт и как один из крупнейших организаторов военно-полевой терапии». ${ }^{21}$ В том же году, после смерти в Ленинграде профессора Г. Ф. Ланга, М. С. Вовси стал его преемником как редактор «Клинической медицины» - одного из самых известных советских медицинских журналов. Главными редакторами этого журнала традиционно были знаменитые терапевты - Д. Д. Плетнев, Г. Ф. Ланг, а после М. С. Вовси - В. Х. Василенко, Ф. И. Комаров.

В научном творчестве М. С. Вовси ведущими были труды по проблемам нефритов (докторская диссертация на тему «Острый нефрит» защищена им в 1938 г.), грудной жабы и инфаркта миокарда и по военно-полевой терапии. Среди его научных трудов военного времени - «Некоторые вопросы военно-полевой терапии» (1941); «Организация и принципы терапевтической помощи в тыловых эвакогоспиталях» (1942); «Нефриты военного времени» (1943);

20 Шульцев Г. П. 50 лет в терапии: На кафедре военно-полевой терапии // http://www.hd13.ru/article/106/

21 Архив РАМН, ф. 9120, оп. 8/2, д. 31, л. 38, 45. 
«Об особенностях клинической патологии в период войны» (1944); «С. П. Боткин как терапевт госпиталей русской армии: к истории военно-полевой терапии» (1944). На ХІІІ Всесоюзном съезде терапевтов в 1947 г. М. С. Вовси обобщил опыт работы советских врачей в программном докладе «Внутренняя медицина в период Великой Отечественной войны 1941-1945 гг.» и показал, что оформившееся в годы войны учение об изменениях внутренних органов у раненых стало новой главой внутренней медицины. Он был также редактором отдела «Терапия» в многотомном издании «Опыт советской медицины в Великой Отечественной войне 1941-1945 гг.».

Магистральными направлениями исследований М. С. Вовси в послевоенные годы стали проблемы нефрологии и переходные формы стенокардии и инфаркта миокарда. Еще в 1940 г. им был написан раздел «Болезни почек» в «Руководстве по внутренним болезням» (под редакцией Г. Ф. Ланга); в 1960 г. эти материалы были переизданы под названием «Болезни системы мочеотделения». Его монография «Острый нефрит» (1946) основывалась на анализе 400 клинических случаев и рассматривала вопросы этиологии, патогенеза, клинической картины, лечения и профилактики этого заболевания. В 1955 г. были опубликованы «Нефриты и нефрозы» (соавтор - Г. Ф. Благман). М. С. Вовси оказывал содействие Г. П. Кулакову - одному из пионеров гемодиализа в нашей стране. Монографии и периодика, материалы съездов и конференций терапевтов, 22 суждения современников свидетельствуют, что к концу 1950-х гг. М. С. Вовси и Е. М. Тареев были признанными лидерами советских терапевтов в вопросах патологии почек. Имя М. С. Вовси занимает заметное место на страницах истории медицины, посвященных развитию учения о болезнях почек в первой половине и середине XX в. (на этой основе с 60-х годов ХХ в. формировалась в СССР нефрология) - наряду с именами М. И. Вихерта, С. С. Зимницкого, Г. Ю. Явейна, Ф. Г. Яновского, Е. М. Тареева.

Исследования клиники М. С. Вовси по вопросам патогенеза, вариантов течения, диагностики и терапии грудной жабы и инфаркта миокарда были отмечены функциональным клинико-

22 Гукасян А. Г. Эволюция отечественной терапевтической мысли (по материалам съездов и конференций терапевтов). - Москва, 1973. 
экспериментальным подходом, с использованием биохимических и инструментальных методик, вошедших в клинику к середине XX в. Накопленный клинический материал (1500 больных стенокардией и почти 1000 пациентов с острым инфарктом миокарда) был положен в основу программного доклада М. С. Вовси XIV съезду терапевтов (1956). В этом докладе, в частности, была дана четкая характеристика промежуточных форм коронарной болезни сердца (по современной терминологии - нестабильная стенокардия и не Q-образующий инфаркт миокарда.) В 1961 г. посмертно были опубликованы его «Клинические лекции болезни сердца и сосудов», которые, к сожалению, лишь частично доносят до нас мастерство Вовси - лектора.) Работы М. С. Вовси в области сердечно-сосудистой патологии позволяют считать его одним из видных представителей кардиологической школы Плетнева.

Лектором М. С. Вовси был исключительным, в совершенстве владел искусством отбирать и упрощать материал для лекции, чтобы все было понятно всем, сохраняя при этом глубину обсуждаемого предмета. Подробно беседуя с больным во время клинического обхода или разбора, он неизменно ободрял и успокаивал его. У него был редкий дар не терять «ариаднину нить» в лабиринте противоречивых клинических фактов, обобщать выявленные симптомы и в доступной аудитории форме выстраивать безупречно логичные диагностические заключения, что делало его лекции и разборы больных незабываемыми для слушателей. Свой опыт преподавателя М. С. Вовси обобщил на конференции терапевтов в 1959 г. в программном докладе «Совершенствование врачей-терапевтов».

Блестящий клиницист, М. С. Вовси диагнозы ставил простые, логичные и точные, в сложных случаях сначала выделял ту часть диагноза, которая не вызывала сомнений, а затем обсуждал спорную его часть; сложных комбинаций лекарств не любил и был противником полипрагмазии.

Л. М. Вовси вспоминала:

«У него существовало понятие - хороший доктор. Это мог быть академик, профессор, молодой ординатор, студент-практикант. Хороший доктор - это было главное определение качества врача. Но и он сам, по-видимому, полностью укладывался в это определение. Он замечательно умел войти в контакт с любым 
больным, понять его страдания, его боль. Когда я ему как-то сказала, почему знакомый так тебя мучает, у него болит палец, а у тебя столько больных с инфарктами, инсультами? Папа сказал: «Ты не понимаешь, у него болит его палец». ${ }^{23}$

Среди его пациентов были видные военачальники (маршалы И. Х. Баграмян, А. М. Василевский, Г. К. Жуков, Б. М. Шапошников и др.), люди искусства (Д. Ойстрах, Л. Коган, С. Рихтер, Э. Гилельс, Г. Уланова, В. Качалов, В. Пашенная) и др.; он был консультантом в Лечебно-санитарном управлении Кремля. Коллеги и все, кому приходилось общаться с М. С. Вовси, отмечали его приветливость, доброжелательность, интеллигентную мягкую манеру поведения, хотя очевидно, что генерал, который создавал терапевтическую службу Красной (Советской) армии и долгое время ею руководил, не мог быть мягким человеком. Лечебная работа заполняла всю его жизнь, но Мирон Семенович любил театр, музыку, прекрасно понимал живопись и «урывал время» для культурного отдыха.

Самое серьезное жизненное испытание выпало на долю генерала и академика М. С. Вовси в начале 1950-х годов, когда органы госбезопасности стали раскручивать знаменитое «дело врачей» апофеоз государственной политики антисемитизма в СССР. Широко известный терапевт, консультант Лечсанупра и лечащий врач видных советских военачальников, не только еврей, но к тому же двоюродный брат трагически погибшего (как теперь установлено, убитого агентами КГБ) председателя Еврейского антифашистского комитета С. М. Михоэлса (настоящая фамилия - Вовси), он оказался идеальной кандидатурой, чтобы поставить его во главе сфабрикованного списка «убийц в белых халатах».

13 января 1953 г. М. С. Вовси был арестован; в «Правде» было опубликовано сообщение ТАСС об аресте группы врачейвредителей:

«Некоторое время тому назад органами госбезопасности была раскрыта террористическая группа врачей, ставивших своей целью путем вредительского лечения сократить жизнь

23 Передача на Радио Свобода 26.01.2003 «Россия как цивилизация. Дети врачей»: Интервью с Л. М. Вовси // http://archive.svoboda.org/programs/ civil/2003/civil.012603.asp 
активным деятелям Советского Союза. В числе участников этой террористической группы оказались проф. Вовси М. С. .. Арестованный Вовси заявил следствию, что он получил директиву «об истреблении руководящих кадров СССР» из США от организации Джойнт через врача в Москве Шимелиовича и известного еврейского буржуазного националиста Михоэлса».

Уже на следующий день, 14 января 1953 г., М. С. Вовси (вместе с В. Н. Виноградовым и А. М. Гринштейном) постановлением президиума был исключен из списка действительных членов АМН СССР как враг народа. ${ }^{24}$

Я. Л. Рапопорт писал:

«М. С. Вовси мне даже рассказал, как от него потребовали признания в том, что он был и немецким шпионом, что при этом требовании он даже расплакался. Он им сказал: «Чего вы от меня хотите? Ведь я признал, что я был американским и анлийским шпионом, неужели этого вам мало? Немцы расстреляли в Двинске всю мою семью, а вы требуете, чтобы я признал, что был их шпионом?» В ответ я получил матерную ругань и требование: «Профессор, ... нечего запираться, был и немецким шпионом.» Я подписал, что был и немецким шпионом». ${ }^{25}$

После смерти Сталина, в ночь с 3 на 4 апреля 1953 г., М. С. Вовси вместе с другими участниками дела врачей был освобожден по докладу МВД, подписанному Л. П. Берией.

Приводим соответствующие документы:

ЗАПИСКА Л. П. БЕРИИ В ПРЕЗИДИУМ ЦК КПСС о привлечении к уголовной ответственности лиц, виновных в убийстве С. М. МИХОЭЛСА и В. И. ГОЛУБОВА №20/Б

2 апреля 1953 г.

Т. МАЛЕНКОВУ Г. М.

В ходе проверки материалов следствия по так называемому «делу о врачах-вредителях», арестованных быв. Министерством государственной безопасности СССР, было установлено, что

24 Архив РАМН, ф. 9120, оп. 8/2, д. 31, л. 38, 45.

25 Рапопорт Я. Л. На рубеже двух эпох: Дело врачей 1953 года. - Москва, 1988. - C. $123,125$. 
ряду видных деятелей советской медицины, по национальности евреям, в качестве одного из главных обвинений инкриминировалась связь с известным общественным деятелем - народным артистом СССР Михоэлсом. В этих материалах Михоэлс изображался как руководитель антисоветского еврейского националистического центра, якобы проводившего подрывную работу против Советского Союза по указаниям из США.

Версия о террористической и шпионской работе арестованных врачей Вовси М. С., Когана Б. Б. и Гринштейна А. М. «основывалась» на том, что они были знакомы, а Вовси состоял в родственной связи с Михоэлсом... 26

\section{ПОСТАНОВЛЕНИЕ ПРЕЗИДИУМА ЦК КПСС}

о фальсификации так называемого дела о врачах-вредителях

3 апреля 1953 г.

Секретно.

П3/І. Доклад и предложения МВД СССР по «Делу о врачах-вредителях»

(тт. Берия, Ворошилов, Булганин, Первухин, Каганович, Сабуров, Микоян, Хрущев, Молотов, Маленков).

1. Принять предложение Министерства внутренних дел СССР:

a) о полной реабилитации и освобождении из-под стражи врачей и членов их семей, арестованных по так называемому «делу о врачах-вредителях», в количестве 37 человек;

б) о привлечении к уголовной ответственности работников б[ывшего] МГБ СССР, особо изощрявшихся в фабрикации этого провокационного дела и в грубейших извращениях советских законов.

$[.$.

7. Настоящее постановление вместе с письмом тов. Берия Л. П. и постановлением специальной следственной комиссии МВД СССР разослать всем членам ЦК КПСС, первым секретарям ЦК Компартии союзных республик, крайкомов и обкомов КПСС.

Президиум ЦК КПСС

26 Россия, XX век: Документы (Лаврентий Берия, 1953) / Стенограмма июльского пленума ЦК КПСС и другие документы. - Составители: В. Наумов, Ю. Сигачев. - Москва, 1999. - С. 23-28; АП РФ, ф. 3, оп. 58, д. 536, лл. 103-107. Подлинник (машинопись с рукописными вставками). 


\section{СООБЩЕНИЕ}

\section{МИНИСТЕРСТВА ВНУТРЕННИХ ДЕЛ СССР}

Министерство внутренних дел СССР провело тщательную проверку всех материалов предварительного следствия и других данных по делу группы врачей, обвинявшихся во вредительстве, шпионаже и террористических действиях в отношении активных деятелей Советского государства.

В результате проверки установлено, что привлеченные по этому делу профессор ВОВСИ М. С., профессор ВИНОГРАДОВ В. Н., профессор КОГАН М. Б., профессор КОГАН Б. Б., профессор ЕГОРОВ П. И., профессор ФЕЛЬДМАН А. И., профессор ЭТИНГЕР Я. Г., профессор ВАСИЛЕНКО В. Х., профессор ГРИНШТЕЙН А. М., профессор ЗЕЛЕНИН В. Ф., профессор ПРЕОБРАЖЕНСКИЙ Б. С., профессор ПОПОВА Н. А., профессор ЗАКУСОВ В. В., профессор ШЕРЕШЕВСКИЙ Н. А., врач МАЙОРОВ Г. И. были арестованы бывшим Министерством государственной безопасности СССР неправильно, без какихлибо законных оснований.

Проверка показала, что обвинения, выдвинутые против перечисленных лиц, являются ложными, а документальные данные, на которые опирались работники следствия, несостоятельными. Установлено, что показания арестованных, якобы подтверждающие выдвинутые против них обвинения, получены работникамиследственной частибывшегоМинистерствагосударственной безопасности путем применения недопустимых и строжайше запрещенных советскими законами приемов следствия.

На основании заключения следственной комиссии, специально выделенной Министерством внутренних дел СССР для проверки этого дела, арестованные ВОВСИ М. С., ВИНОГРАДОВ В. Н., КОГАН Б. Б., ЕГОРОВ П. И., ФЕЛЬДМАН А. И., ВАСИЛЕНКО В. Х., ГРИНШТЕЙН А. М., ЗЕЛЕНИН В. Ф., ПРЕОБРАЖЕНСКИЙ Б. С., ПОПОВА Н. А., ЗАКУСОВ В. В., ШЕРЕШЕВСКИЙ Н. А., МАЙОРОВ Г. И. и дрУгие привлеченные по этому делу полностью реабилитированы в предъявленных им обвинениях во вредительской, террористической и шпионской деятельности и, в соответствии со ст. 4 п. 3 УголовноПроцессуального Кодекса РСФСР, из-под стражи освобождены.

Лица, виновные в неправильном ведении следствия, арестованы и привлечены к уголовной ответственности. ${ }^{27}$

27 Россия, XX век: Документы (Лаврентий Берия, 1953) / Стенограмма июльского пленума ЦК КПСС и другие документы. - Составители: В. Наумов, Ю. Сигачев. - Москва, 1999. - С. 23-28; АП РФ, ф. 3, оп. 58, д. 423, лл. 1-4. Копия. 
По воспоминаниям дочери, М. С. Вовси «возвратился домой с кроваво-синюшными «браслетами» на руках и на ногах. Это были следы от тяжёлых наручников и кандалов, которые надевали на заключённых, что подробно описал в своей книге Яков Львович Рапопорт, но о чём не рассказывал папа. Он только старался опустить рукава сорочки таким образом, чтобы дома никто эти следы не заметил». ${ }^{28}$

На следующий после освобождения день М. С. Вовси приступил к работе и прочитал лекцию слушателям ЦИУ врачей; 10 апреля 1953 г. он, будучи полностью реабилитированным, вновь (второй раз в жизни, как и другие академики - «враги народа») стал действительным членом Академии медицинских наук СССР.29

Последнее десятилетие жизни М. С. Вовси было омрачено еще одним тяжелым испытанием - его настигла мучительная смертельная болезнь, он потерял ногу. Несмотря на это, до конца апреля 1960 г. он ещё ездил в клинику, читал лекции, разбирал сложные диагностические случаи. Свидетельство его мудрости и исключительного мужества оставил нам Я. Л. Рапопорт: «Спустя шесть лет после освобождения, которые он провел в заслуженном почете крупного ученого, замечательного врача и сердечного человека, у него развилась саркома ноги, потребовавшая ее ампутации (он вскоре после этого умер). Я навестил его на следующие (или вторые) сутки после операции. Он был в слегка возбужденном эйфорическом состоянии и сказал мне: «Разве можно сравнить мое теперешнее состояние с тем, которое было тогда? Теперь я потерял только ногу, но остался человеком, а там я перестал быть человеком».

Находясь после операции в санатории в Волынском, М. С. Вовси диктовал Т. Н. Герчиковой свою книгу «Болезни системы мочеотделения», изданную посмертно. И, конечно, он продолжал лечить, консультировать.

Маршал А. М. Василевский писал в письме к дочери М. С. Вовси:

«... Мирон Семенович был и остается одним из самых дорогих для меня и всей нашей семьи человеком, которому мы были и остаемся сердечно привязаны, а также глубоко благодарны за его незабываемое внимание к нам, за ту огромную помощь, которую

28 Воспоминания Л. М. Вовси // http://lifshits.org/1953-LV.doc

29 Архив РАМН, ф. 9120, оп. 8/2, д. 55. 
он своими познаниями и практическим опытом оказал мне в моей ответственной работе, за ту неоценимую помощь, которую он оказывал на протяжении всей войны нашим Вооруженным Силам. Я счастлив тем, что моя судьба так близко свела меня с таким замечательным, незабываемым человеком. Разве мы можем забыть хотя бы такие минуты, когда он за несколько недель до своей смерти нашел силы и возможность с забинтованной ногой принимать участие в консультации, когда я был тяжело болен, но, оказывается, не так тяжело, как был болен он».

Последний месяц смертельно больной М. С. Вовси провел в своем кабинете в Боткинской больнице; в ночь с 5 на 6 июня 1960 г. его не стало. Он похоронен на Донском кладбище.

Врачебные и научные взгляды М. С. Вовси развивали его многочисленные ученики. Кроме названных выше сотрудников клиники, к ним относится и уролог-нефролог член-корреспондент АМН СССР Г. П. Кулаков - пионер гемодиализа в Москве, который подчеркивал, что работал на стыке урологии и терапии, и называл своими учителями выдающегося уролога А. П. Фрумкина и М. С. Вовси. Для истории МГМСУ особый интерес представляет, что ученик М. С. Вовси и его преемника по кафедре А. З. Чернова профессор В. Н. Орлов в 1974 г. организовал кафедру терапии № 1 на факультете повышения квалификации врачей (последипломного образования) Московского стоматологического института (ныне МГМСУ), руководил ею до конца жизни (1989); кафедра стала родоначальницей системы терапевтических кафедр на этом факультете, включая кафедру кардиологии.

Середина 20-го века была временем, когда столица активно «всасывала» лучших специалистов, в том числе и клиницистов, со всех концов Советского Союза, чему способствовала целенаправленная политика государства. Но и при самой высокой конкуренции выдающийся московский врач М. С. Вовси был очень заметен, популярен. Наряду с В. Х. Василенко, В. Н. Виноградовым, он считался виртуозом врачебного диагностического мастерства. Как и А. Л. Мясников, Е. М. Тареев, И. А. Кассирский, он входил в число лидеров, определявших движение научной терапевтической мысли. У него была слава лучшего лектора в клинике внутренних болезней. Когда его хоронили, директор Института терапии АМН СССР А. Л. Мясников сказал: «Он был самый умный из нас». 


\section{Akadēmiķis M. Vovsi un \\ "ārstu lieta"}

\section{Kopsavilkums}

Rakstā izklāstīta akadēmiķa Mirona Vovsi (1897-1960) biogrāfija, viņa radošā darbība, kā arī atspoguḷots zinātnieka traǵiskais liktenis, kad PSRS izvērsās t. s. "ārstu lietas” kampaņa.

Talantīgais terapeits dzimis ebreju ǵimenē Krāslavā. Medicīnas studijas vin̄š sāka Tartu, turpināja Maskavā, kur vēlāk pievērsās gan pasniedzēja, gan pētniecības darbam. 1927. gadā pētnieks pusgadu stažējās Frankfurtē pie Mainas, Berlīnē un Ķ̄1̄lē, pievēršoties audu ķīmiskā sastāva, asins masas noteikšanas metodēm, zarnu trakta patoloğiju noteikšanas paņēmieniem u. tml. jautājumiem. 1930. gadā viņš izveidoja padomju mediķu profesionālo žurnālu (“Советский врач”). M. Vovsi zinātnisko interešu lokā bija nefroloǵijas jautājumi. Viṇu toreizējā PSRS var uzskatīt par celmlauzi šajā medicīnas virzienā.

1936. gadā M. Vovsi aizstāvēja doktora disertāciju un kḷuva par profesoru, ar̄̄ par Trešās terapijas katedras vadītāju Ārstu kvalifikācijas celšanas centrālajā institūtā slavenajā Botkina slimnīcā, kur strādāja līdz mūža beigām.

1941. gadā viṇš kḷuva par Sarkanās armijas galveno terapeitu un Otrā pasaules kara gados pievērsās terapeitiskās palīdzības organizācijai militārajās vien̄̄bās, veidoja lauka terapijas pamatus un Botkina slimnīcā 1944. gadā vadīja Militārās klīniskās un lauka terapijas katedru.

1948. gadā viņu ievēlēja par akadēmiķi PSRS Medicīnas Zinātņu akadēmijā. Pienākumu loks paplašinājās ar redaktora darbu profesionālajā klīniskās medicīnas žurnālā (“Клиническая медицина”). Pētījumos uzzinātais tika aprakstīts un publicēts grāmatās, piemēram, nodaḷa par nieru slimībām iekšksīgo slimību rokasgrāmatā, monogrāfija par akūtu nefrītu, kopdarbs ar G. Blagmanu - par nefrītiem un nefrozēm.

M. Vovsi bija gan lielisks klīnicists un virtuozs diagnosts, gan prasmīgs lektors. Tomēr arī viņam negāja secen dramatiskie notikumi 20. gs. 50. gadu sākumā, kad PSRS drošības institūcijas izvērsa antisemītisko kampaņu, kas pazīstama kā "ārstu lieta”. 1953. gada janvārī ǵenerāli un akadēmiķi M. Vovsi arestēja, apsūdzot par kaitniecību, tomēr jau aprīlī 
viņu atbrīvoja, un jau nākamajā dienā M. Vovsi devās lasīt lekciju. Pēc sešiem gadiem izcilais ārsts sasirga un nomira 1960. gada naktī no 5. uz 6. jūniju.

M. Vovsi atstāto pētniecisko mantojumu attīstīja un paplašināja viņa kolēǵi un audzēkņi - urologs nefrologs G. Kulakovs, profesors V. Orlovs un citi.

\section{Academician M. Vovsi and "the Doctors' Plot"}

\section{Abstract}

The article discusses the biography and work of the academician Miron Vovsi (1897-1960), as well as the tragic life of the scientist, when "the Doctors' Plot" campaign developed in the former USSR.

The talented therapist was born in a Jewish family in Krāslava (Latvia). He started his studies in medicine started in Tartu (Estonia), continued in Moscow (USSR) where he also took role as the lecturer and the researcher. In 1927, for a six-month period, M. Vosi undertook his traineeship in Frankfurt am Main, Berlin and Kiel (Germany), which is where he focussed on methods of defining chemical components of tissue and blood mass, methods of indicating pathologies in intestinal tract and questions alike. In 1930, he established the professional magazine for soviet doctors “Советский врач” (Eng. "Soviet Doctor”). M. Vovsi’s scientific interests included questions of nephrology. He may be recognised as the initiator of this branch of medicine in the former USSR.

In 1936, M. Vovsi defended his $\mathrm{PhD}$ and became a professor, and the Head of the Third Therapy Department at the Central Institute of Doctor's professional development in the well-known Botkin Hospital, where he worked until his last days of life.

In 1941 he became the chief therapist of the Soviet Red Army, and during the Second World War assisted therapeutic aid organisations in military units, initiated the foundation of the field therapy, and in 1944 in Moscow Botkin Hospital was the head of Military Clinical and Field Therapy Department. 
In 1948 he was elected academician at the USSR Academy of Medical Sciences. The scope of responsibilities grew by becoming an editor at the professional clinical medicine magazine "Клиническая медицина" (Eng. "Clinical Medicine"). The conclusions were described and published in books.

M. Vovsi was an excellent clinician, virtuous diagnost, and a knowledgeable lecturer. However, the dramatic events of the 1950s had direct influence on M. Vovsi, when safety institutions of the USSR developed its anti-Semitic campaign, known as “the Doctors' Plot". In January, 1953, the general and academician M. Vovsi was arrested, incriminating sabotage; however, he was already released in April, and already on the next day he went to read his lecture. Six years later, the excellent doctor fell seriously ill and in 1960, during the night between the fifth and sixth of June, he died.

The inheritance left by M. Vovsi was developed and enhanced by his colleagues and students - the urologist nephrologist G. Kulakov, the Professor V. Orlov and others.

\section{Владимир Иосифович Бородулин, профессор, Д. м. н. \\ НИИ Истории медицины Российской академии наук, Москва vborodul@mail.ru}

\section{Татьяна Никоновна Герчикова}

к. м. н., доцент

Городская клиническая больница имени С. П. Боткина Департамента здравоохранения г. Москвы

\section{Константин Анатольевич Пашков,} профессор, д. М. н.

Московский государственный медико-стоматологический университет имени А.И.Евдокимова historymed@mail.ru

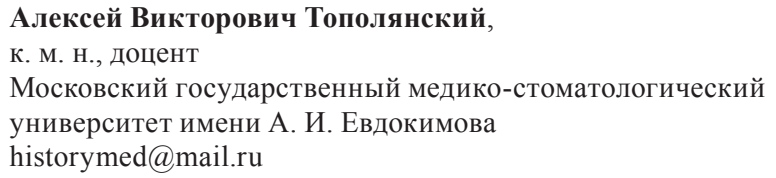

